\title{
TECHNIKA KOMUNIKOWANIA PRAWA W DECYZJACH I ZARZĄDZENIACH ADMINISTRACYJNYCH
}

\author{
MARIA TERESA LIZISOWA \\ Uniwersytet Pedagogiczny \\ KEN w Krakowie \\ 31-416 Kraków, ul Dobrego Pasterza 29/24 \\ lizis@tlen.pl
}

Streszczenie: Artykuł jest wykładem językoznawczym na temat wzajemnych
związków między językiem prawnym a językiem prawniczym na płaszczyźnie
semantycznej, syntaktycznej, pragmatycznej i stylistycznej. Autorka dokonała
analizy decyzji i zarządzeń administracyjnych ze względu na status języka
i lingwistyczne rozumienie komunikacji. Stwierdziła, że decyzyjny akt urzędowy
jest świadectwem twórczego odczytania macierzystego tekstu ustawy przez
urzędnika pełniącego rolę interpretatora i decydenta w stosowaniu prawa. Urzęd-
nik wypełnia obowiązek narzucony mu przez normę kompetencyjną wysłowioną
przepisami w aktach prawnych. Posiłkuje się regułami języka według wyuczo-
nych i ustawowo zalecanych reguł wykładni prawa. Poprzez ewokację w odbio-
rze treści artykułów ustawy w dokumentach administracyjnych znaczenia i kon-
teksty prawne ulegają swoistemu przyswojeniu przez urzędnika-interpretatora.
Następnie podlegają adaptacji do odnośnych sytuacji prawnych, 
a w konsekwencji następuje proces uniwersalizacji wiedzy o prawie stanowionym, ponieważ urzędnik-decydent wpisuje indywidualną znajomość treści ustawodawczych w konkretną rzeczywistość prawną własnej wspólnoty komunikacyjnej.

Słowa klucze: język prawny, język prawniczy, tekst ustawodawczy, tekst urzędowy, komunikacja instytucjonalna, stanowienie prawa, odbiór i dekodowanie tekstu ustawy, wykładnia decyzyjna prawa

\title{
TECHNIQUES OF LAW COMMUNICATION IN ADMINISTRATIVE DECISIONS AND ORDERS
}

\begin{abstract}
The article is a linguistic lecture on mutual relations between legal language and legislative language on the semantic, syntactic, pragmatic and stylistic planes. The author analysed decisions and official regulations with regard to the status of language as well as the linguistic understanding of communication. A decisive official act is a testimony of the primary reading of the text of a legislative act by an official, fulfilling the role of an interpreter and a decision maker in applying law. He fulfils a duty imposed on him by the norm of competence, verbalised in principles of legal acts. In the process of organizing a legal text, he makes use of the rules of language, according to both the studied and the statutorily recommended rules of the interpretations of law. Through evoking the content of legal articles in official documents, therefore through concretization of legal norms in the process of reception, the legal meanings and contexts undergo a certain kind of assimilation by an official-interpreter. Later, they become adapted in corresponding legal situations, and finally, as a consequence, a process of universalization of knowledge about the established law takes place, because an official-decision maker inscribes his personal knowledge of the legislative content into a specific legal reality of his own community.
\end{abstract}

Key words: legal language, legislative language, text of a legislative act, official text, institutional communication, establishment of law, reception and decoding the text of a legislative act, decisive interpretation of law.

\section{Wstęp}

Przedmiotem badań w artykule jest dyskurs prawniczy urzędników administracji publicznej. Analizie językoznawczej zostaną poddane teksty urzędowe wydane $\mathrm{w}$ postępowaniu administracyjnym $\mathrm{w}$ spra- 
wach uregulowanych ustawowo. W tekstach urzędowych reguły języka prawnego, występujące w tekstach ustawodawczych, są przekładane na reguły języka prawniczego i stosowane do konkretyzowania prawa w obrocie ${ }^{1}$.

W analizie tekstów urzędowych rozróżniam cechy systemowe socjolektu urzędowego od cech idiolektów urzędników. Przy założeniu, że język prawniczy ma charakter idealnego socjolektu w odróżnieniu od konkretnych idiolektów (Grabias 1993: 223), problemem badawczym jest, w jakim stopniu cechy tekstów postanowień administracyjnych są porównywalne z cechami tekstów ustawodawcy, które są wzorcem dla rozstrzygania konkretnych problemów społecznych.

Pisma urzędowe w postępowaniu administracyjnym są tekstami przynależnymi do języka prawniczego ze względu na cechy pragmatyczne i stylowe. Analizowane teksty to pisma urzędowe organów administracji, w praktyce urzędniczej tytułowane „decyzje” lub ,zarządzenia", które na wniosek obywateli są wydawane przez władzę wykonawczą na podstawie właściwych przepisów prawnych i wyznaczają sposób wykonania ustawy. Celem badań jest naukowe rozpoznanie kwestii językowych w obrębie zjawisk prawnych, a także w praktyce stosowania prawa. Wszak decyzyjne pisma urzędowe są świadectwem tego, jak przebiega interpretacja tekstu prawnego i jak zostało uzasadnione zastosowanie przepisów prawnych w działalności urzędowej interpretatora. Teksty urzędowe są swoistą wykładnią prawa i zarazem decydują o wykonaniu prawa $\mathrm{w}$ faktycznej sytuacji prawnej (Lizisowa 2016: 102-104).

W badaniach nad konkretyzacją przepisów prawnych w pismach urzędowych nawiązuję do propozycji Franciszka Studnickiego, który zalecał rozważanie procesów komunikacyjnych w funkcjonowaniu porządku prawnego metodami językoznawstwa teoretycznego na dwóch płaszczyznach: semantycznej i pragmatycznej. Analiza semantyczna tekstu ma obejmować wytwarzanie i odbieranie sygnałów oraz przypisywanie sygnałom znaczenia. W płaszczyźnie pragmatycznej dyskursu analizie podlega sytuacja dotyczącej oddziaływań wywiera-

\footnotetext{
${ }^{1}$ Niniejsza publikacja nawiązuje do referatu pt. Lingwistyczne aspekty konkretyzacji przepisów prawnych $w$ pismach urzędowych, wygłoszonego na I Kongresie Języka Urzędowego w październiku 2012 roku. W publikacji Kancelarii Senatu (Warszawa 2013) zamieszczono opracowanie materiałów kongresowych przez Małgorzatę Lipińską na podstawie wygłoszonego przez prelegentkę komentarza do prezentacji komputerowej. W tym ujęciu tematu wykorzystano materiał empiryczny prezentowany na slajdach.
} 
nych przez sygnały (Studnicki 1969: 18-21). Warto dodać, że aspekty semantyczne i pragmatyczne tekstu mają związek z gramatyką (syntaktyką) teksu. W analizie lingwistycznej gatunku tekstu biorę pod uwagę wpływ języka prawnego i języka prawniczego nauk prawnych na treść i kształt językowy tekstu urzędowego. Zgodnie z postulatem metodycznym F. Studnickiego przyjmuję, że język niniejszych analiz semantycznych i pragmatycznych z punktu widzenia lingwistyki jest językiem dyskursywnym ukierunkowanym na interpretację tego, jak treści zawarte $\mathrm{w}$ tekstach stanowienia prawa są przekazywane $\mathrm{w}$ tekstach stosowania prawa. Według teorii lingwistycznych komunikowanie zjawisk prawnych na poziomie ustawodawczym, na poziomie obrotu prawnego oraz na poziomie lingwistycznej refleksji nad sprzężeniem między tekstem ustawodawczym a tekstem urzędowym to nie tylko przekazywanie treści będącej informacją expressis verbis, ale również sugerowanie presupozycji, które zapewnia kompetencja interlokutorów w obrębie kultury prawnej.

\section{Przedmiot stanowienia prawa a przedmiot stosowania prawa}

Teoria języka narzuca pewne reguły potraktowania mowy ludzkiej w funkcjonowaniu społecznym. Faktem bezdyskusyjnym jest ciągłe trwanie międzyludzkiej komunikacji słownej. Komponenty myślowe (pojęcia) i znaki języka komunikatu składają się na teksty podlegające interpretacji w dyskursie (Lizisowa 2012: 25).

1.1. Tekstem ustanawiającym i komunikującym prawo jest powszechnie obowiązujący akt prawny uchwalony przez parlament, podpisany przez prezydenta i publicznie ogłoszony - jest nim ustawa, także kodeks czy rozporządzenie. Decyzja administracyjna jest aktem stosowania prawa wydanym przez organ administracyjny w trybie określonym przez Kodeks postępowania administracyjnego (k.p.a.)².

\footnotetext{
${ }^{2}$ Zob. stosowne przepisy k.p.a.: Art. 104. § 1. Organ administracji publicznej załatwia sprawę przez wydanie decyzji, chyba że przepisy kodeksu stanowią inaczej. § 2 . Decyzje rozstrzygają sprawę co do jej istoty w całości lub w części albo w inny sposób kończą sprawę w danej instancji. Art. 123. §1. Kodeks ustanawia, jakie elementy obligatoryjne powinna zawierać decyzja administracyjna: Art. 107. § 1. Decyzja zawiera: 1) oznaczenie organu administracji publicznej; 2) datę wydania; 3) oznaczenie strony lub stron; 4) powo30
} 
Urzędy wydają także zarządzenia będące wewnętrznymi zasadami postępowania w danej sprawie. W tych tekstach ustawodawczych i administracyjnych komunikacja międzyludzka ma charakter instytucjonalny.

Komunikacja instytucjonalna przebiega hierarchicznie od nadawcy do odbiorców w trzech sferach. Tekst ustawy wyraża intencję ustawodawczą $\mathrm{w}$ formie przepisów prawnych ustanawiających normy prawne jako reguły postępowania kompetentnych podmiotów prawnych. Według tych reguł ma postępować urzędnik kompetentny w rozstrzyganiu spraw indywidualnych obywateli, wyszukując informacji prawnych dotyczących postępowania podmiotów prawnych podległych jego kompetencji, to jest podmiotu uprawnionego i obowiązanego $\mathrm{w}$ danej sprawie. Adwersarzami tej komunikacji nie są konkretne osoby, lecz określone kategorie osób, które istnieją tylko jako punkty odniesienia $\mathrm{w}$ relacjach interpersonalnych. Natomiast w postępowaniu administracyjnym następuje proces dekodowania przepisów prawnych i zastosowania ich w życiu społecznym. Adwersarzami tej komunikacji są konkretne osoby uczestniczące w procesie decyzyjnym stosowania prawa. Dany urzędnik załatwia określone sprawy wiadomych obywateli zgodnie z obowiązującymi przepisami prawnymi, wydając polecenia wdrażające w życie postanowienia ustawy.

Przykładem może być decyzja administracyjna i zarządzenie administracyjne. Polecenia urzędnika są kierowane do obywatela, którym jest osoba fizyczna wnioskująca o ich wydanie. Efektem końcowym jest przyjęcie postanowień urzędu przez jej adresata. Przebieg komunikacji instytucjonalnej, począwszy od mowy ustawodawcy aż do zastosowania przepisów ustawy w działalności gospodarczej, jest ukierunkowany na działanie tak podmiotów kompetentnych do podejmowania postanowień administracyjnych, jak i na działanie osób ubiegających się o takie działanie administracyjne. W komunikacji instytucjonalnej typy wypowiedzi są realizowane jako ustawodawcze akty mowy i podporządkowane im decyzyjne akty mowy. Zob. przebieg komunikacji instytucjonalnej od aktu stanowienia prawa do realizacji postanowień administracyjnych w schemacie 1 .

łanie podstawy prawnej; 5) rozstrzygnięcie; 6) uzasadnienie faktyczne i prawne; 7) pouczenie, czy i w jakim trybie służy od niej odwołanie oraz o prawie do zrzeczenia się odwołania i skutkach zrzeczenia się odwołania; 8) podpis z podaniem imienia i nazwiska oraz stanowiska służbowego pracownika organu upoważnionego do wydania decyzji, a jeżeli decyzja wydana została w formie dokumentu elektronicznego - kwalifikowany podpis elektroniczny. 
Schemat 1. Przebieg komunikacji instytucjonalnej

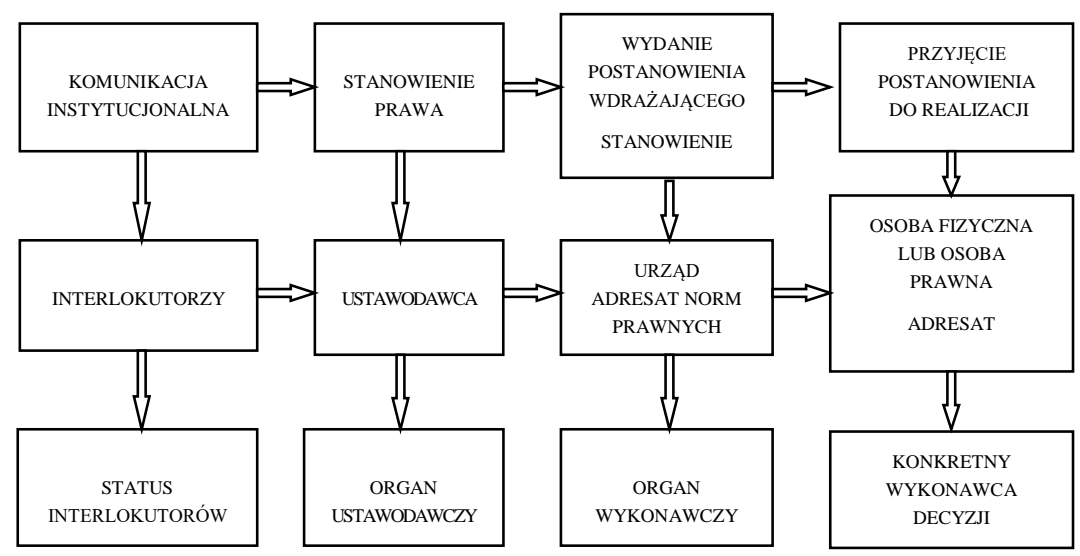

Obszar stanowienia i obowiązywania prawa obejmuje: 1) zamysł ustawodawczy, akcję ustanawiania prawa w procesie legislacji, w wyniku czego powstaje przekaz $\mathrm{w}$ formie tekstu prawnego; 2) reakcję organu administracyjnego jako obowiązywanie postanowień ustawy, percepcję przekazu i efekt wykonania postanowień ustawy w formie decyzji lub zarządzenia administracyjnego; 3) reakcję obywatela jako obowiązywanie postanowień urzędu, uznanie lub zaprzeczenie ich zgodności z postanowieniami ustawy i wykonanie postanowień urzędu lub odwołanie się od nich.

1.2. Akt stanowienia prawa - ustawa - jest tekstem macierzystym, składającym się z przepisów prawnych. Przepisem prawnym jest seria zapisanych sygnałów optycznych, które należy rozumieć jako normy prawne generalne. Agencją autoryzowaną do wytwarzania przepisów prawnych jest ustawodawca. Ustawodawca oddziaływa na adresata, który ma obowiązek postępowania według wyznaczonych mu ról społecznych [Studnicki 1969: 25]. Adresatem normy prawnej kompetencyjnej jest organ administracyjny - człowiek lub zespół ludzi. Jest to adresat, któremu akt ustawodawczy nadaje kompetencje do wydawania aktów decyzyjnych pod rządem ustawy. Adresatem decyzji lub zarządzenia jest obywatel przyjmujący postanowienia urzędu i obowiązany do działania według nich.

Prawo stanowi ustawodawca performatywnym aktem mowy, czyli wypowiedzią sprawczą, normatywną, nie podlegającą ocenie 
w kategoriach prawdy i fałszu. W teorii aktów mowy Johana L. Austina wypowiedź sprawcza:

Jest to decyzja, że coś ma być takie, w odróżnieniu od sądu, że jest takie; jest ona obroną tego, co powinno być takie w przeciwieństwie do oceny; jest przyznaniem czegoś w odróżnieniu od oszacowania; jest wyrokiem, w odróżnieniu od osądu (Austin: 1993: 699).

Angielscy prawnicy używają terminu performative na oznaczenie klauzul dokumentów służących przelaniu tytułu własności. W kulturze prawa stanowionego termin wypowiedź performatywna odnosi się do aktów stanowienia prawa. Sformalizowany według tradycyjnych zasad akt stanowienia prawa tworzą: 1) rama tekstowa ze składnikiem inicjalnym w formie preambuły, 2) rozczłonkowany na rozdziały i paragrafy korpus tekstu zawierający redakcje przepisów prawnych, 3) sygnały końca informujące o obowiązywaniu przepisów zawartych w korpusie tekstu. O uznaniu takiej wypowiedzi za performatywną przemawia forma stylistyczna, jakość semantyczna predykatów i argumentów zdań oraz sytuacja pozajęzykowa. Wykładnikiem performatywności jest czasownik ustanawiam(y), lecz performatywną funkcję pełni tekst ustawodawczy niezależnie od tego, czy taki czasownik został w nim użyty expressis verbis, czy nie. Performatywność obejmuje pozajęzykowy element konwencjonalny. W formie stylistycznej przepisy prawne w tekście ustawodawczym mają trójpoziomową strukturę: performatywny wykładnik ramy tekstowej, normatywną strukturę przepisu prawnego oraz modalny wykładnik referencyjny w zdaniu normatywnym (Malinowski 2006: 103, Lizisowa 2006: 40).

Rama wypowiedzi uzyskuje zdolność aktu illokucyjnego jako akt woli ustawodawcy. Wykładnik referencyjny to zdanie normatywne, które zawiera modalizator $\mathrm{w}$ postaci czasowników powinien, może, ma prawo lub ich ekwiwalentów tekstowych (predykaty modalne, orzekające o obowiązkach i uprawnieniach podmiotów), a także argumenty osobowe (nazwy podmiotów) i argumenty rzeczowe (nazwy przedmiotów) (Lizisowa 2009: 30-36) . $^{3}$

\footnotetext{
${ }^{3}$ Analizując tekst aktu ustawodawczego można pominąć kwestię wykładników performatywności i przyjąć, że tekst ten jest z natury performatywny, bo ustanowiony w sposób rytualny jako akt sprawczy. Jednak w interpretacji przepisów prawnych, a szczególnie w teorii wykładni prawniczej, istotne jest rozróżnienie performatywności i modalności macierzystego tekstu prawnego.
} 
1.3. Decyzja czy zarządzenie władz administracyjnych jest indywidualnym aktem stanowienia prawa $\mathrm{z}$ woli urzędu, skierowanym do jednostkowego adresata. Decydent-urzędnik działa w imieniu urzędu na wniosek osoby fizycznej lub prawnej, która żąda danej czynności ze względu na swój interes prawny. Treścią decyzji jest przyznanie uprawnienia na działalność gospodarczą, handlową bądź gastronomiczną, zezwolenie budowlane, zezwolenie celne, postanowienie o lokalizacji inwestycji, pozwolenie na prowadzenie pojazdów mechanicznych, orzeczenie w sprawach dotyczących aktów stanu cywilnego, o pomocy społecznej, o przydziale lokalu, o przyznaniu i podwyższeniu emerytury lub renty itd. (Malinowska 2001: 90-101). Z mocy performatywnej aktu ustawodawczego decydent jest obowiązany do wydania meta-performatywnego aktu decyzyjnego w konkretnej sytuacji faktycznej i prawnej.

Rama wypowiedzi decyzyjnej jest bardzo ważna, nadaje bowiem potencjał illokucyjny konkretnemu aktowi mowy urzędnika, nadbudowanemu nad aktem mowy ustawodawcy. Wykładnik referencyjny meta-performatywności to zdanie deontyczne, które zawiera czasowniki ustalam, zarządzam, postanawiam itp., albo bezosobowe jego ekwiwalenty tekstowe: zarządza się itp.

1.4. Intencja komunikacyjna stanowienia prawa i stosowania prawa zdecydowanie wpływa na cechy gatunkowe tekstów - ustawy i postanowień administracyjnych. Między tekstem ustawy a tekstem postanowienia administracyjnego istnieje sieć powiązań treściowych i formalnych, zob. schemat 2.

Schemat 2. Związki formalne i treściowe pomiędzy wystąpieniami komunikacyjnymi ustawodawcy i odbiorem komunikatów przez urzędnika

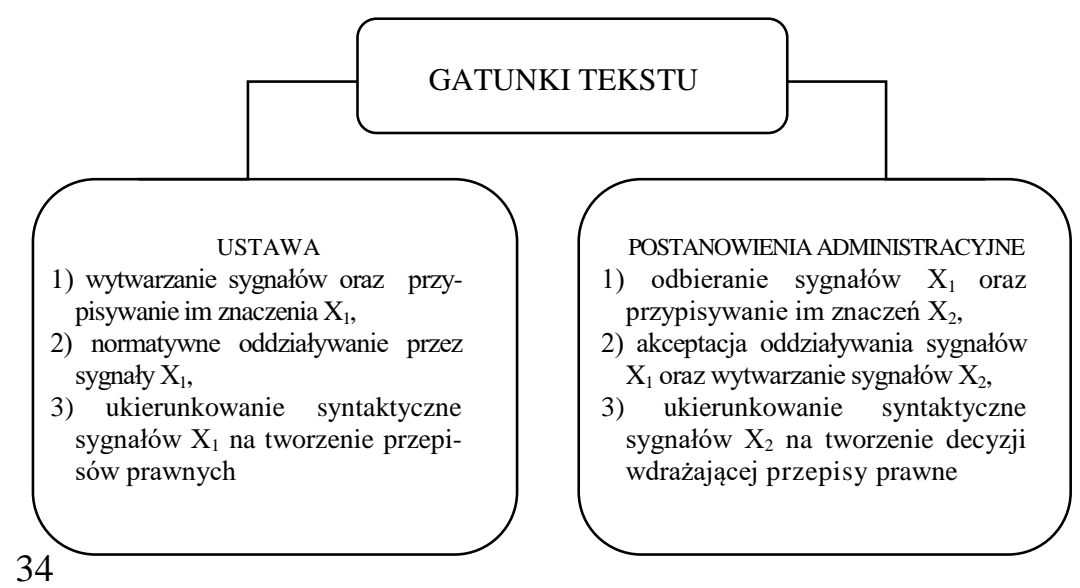


Powiązania i relacje pomiędzy wystąpieniami komunikacyjnymi ustawodawcy i decydenta przebiegają na płaszczyźnie semantycznej, syntaktycznej i pragmatycznej. Sygnały semantyczne $\left[\mathrm{X}_{1}\right]$ są nadawane przez ustawodawcę $\mathrm{w}$ tekstach stanowienia prawa, a odbierane są przez urzędnika, który przypisuje im inne znaczenia $\left[\mathrm{X}_{2}\right]$. Intencjonalna postawa ustawodawcza przekłada się na postawę decyzyjną jako akceptacja treści stanowionych, a w dalszej kolejności jako przetworzenie sygnałów odbieranych $\left[\mathrm{X}_{1}\right]$ na sygnały decyzyjne $\left[\mathrm{X}_{2}\right] \mathrm{z}$ intencją obowiązywania tych drugich $\mathrm{w}$ danej sytuacji społecznej. Syntaktyczny kształt tekstu prawnego, macierzystego, jest ukierunkowany na przekazywanie treści $\left[\mathrm{X}_{1}\right]$, której następstwem jest obowiązywanie zawartych w nim norm prawnych generalnych, zaś kształt tekstu urzędowego jest ukierunkowany na przekazywanie treści decyzyjnych $\left[\mathrm{X}_{2}\right]$, których następstwem jest obowiązywanie meta-norm w obrocie prawnym.

Uszczegółowienie przepisów ustawy w urzędowych aktach decyzyjnych polega na zmianie struktury tekstu i cech dyskursu. Wydanie dokumentu decyzyjnego jest czynnością konwencjonalną, powiązaną z tekstem prawnym poprzez intencjonalność ustawodawcy, akceptabilność urzędu oraz sytuacyjność zależną od okoliczności zewnętrznych wobec zamierzonego celu ustawodawcy, a także od potencjału, jaki urzędnik zechce przeznaczyć na przetworzenie tekstu. Dokument decyzyjny wydany przez urząd jest bowiem świadectwem interpretacji przepisów ustawy i wyrazem ich konkretyzacji.

1.4. Funkcją tekstu prawnego jest sterowanie postępowaniem urzędów. W tekście ustawy jest monitorowana sytuacja, którą adresaturzędnik odbiera jako scenariusz dla sytuacji wymaganej rutynowo, natomiast swoje decyzje kieruje głównie do zainteresowanych stron, a w presupozycji do środowiska prawniczego z uwagi na konsekwencje odwołania się stron od decyzji. Cechą wspólną dyskursu prawnego i dyskursu prawniczego jest to, że są one dialogami asymetrycznymi z dominacją władzy nad obywatelem.

Schemat konkretyzacji przepisów prawnych w decyzyjnych pismach urzędowych ma umocowanie w Kodeksie postępowania administracyjnego. Na podstawie przepisów prawa administracyjnego organ aparatu państwowego „rozstrzyga sprawę co do jej istoty w całości lub w części albo w inny sposób kończy sprawę w danej instytucji” (k.p.a. $104, \S 2$.). Kompetencje organów podejmujących decyzje oraz procedury podejmowania decyzji funkcjonują $\mathrm{w}$ kręgu kultury prawnej będącej tłem działań administracyjnych z mocy ustawy. 


\section{Decyzja administracyjna jako tekst prawniczy}

Tekst ustawy ma strukturę złożoną z przepisów prawnych i zdań normatywnych dostosowaną do stanowienia norm prawnych, a tekst decyzji administracyjnej ma strukturę zdania deontycznego wraz z uzasadnieniem, konkluzją i pouczeniem o obowiązywaniu decyzji. Modelem produkcji tekstu ustawy jest stanowienie norm prawnych generalnych $\mathrm{w}$ drodze legislacji obowiązującej powszechnie, a modelem recepcji tekstu ustawy jest zastosowanie norm prawnych indywidualnych przez wydanie decyzji administracyjnej i nakazanie konkretnym osobom obowiązku jej przyjęcia. Istnieje ciągłość komunikacyjna między niezawisłą kompetencją ustawodawcy, a kompetencją urzędu reprezentowanego przez urzędnika co do wydawania decyzji administracyjnych z mocy ustawy.

Tekst decyzji administracyjnej jest intertekstem w stosunku do tekstu ustawy jako pre-tekstu. Wzorzec tekstu decyzji jest schematem pojęciowym reprezentującym zbiór typowych tekstów. Ma podłoże kompozycyjne i stylistyczne w regułach kognitywnych oraz w spójności logicznej, jest spójny kompozycyjnie i intencjonalnie w organizacji języka i w realizacji systemu językowego, jest uzależniony od gatunku mowy i stylu (Lizisowa 2016: 123-124). By tekst był strategią działania językowego musi być znany nadawcy i odbiorcy. Wskazówki dla redaktora decyzji administracyjnej jako gatunku tekstu podaje art. 107 k.p.a.

2.1. Komunikowanie prawa przebiega $\mathrm{w}$ sferze napięć między prawodawcą a adresatem norm wysłowionych w tekście ustawy. Relacje osobowe w urzędowej komunikacji przebiegają w ten sposób, że ustawodawca przewiduje zachowanie urzędnika. Ekspresja komunikowana w strukturze tekstu ustawowego uwzględnia rolę bezpośredniego odbiorcy komunikatu. Oddziaływanie prawodawcy na adresatówobywateli odbywa się przy wsparciu podmiotów kompetentnych, jakimi są organy administracji, za pośrednictwem których obywatele mogą korzystać z przyznanych im upoważnień czy uprawnień. Zależność między komunikatem nadanym a komunikatem odebranym dotyczy działania prawa (Zieliński 2002: 50-52).

Decyzja administracyjna jest dokumentacją odbioru komunikatów ustawodawcy oraz przetwarzania tych komunikatów. Jest tekstem o charakterze dyskursywnym, w którym czynności lektury nie zostały stematyzowane, lecz odesłane do przepisów prawnych oznaczonych 
jako artykuły ustaw. Odesłania pokazują pośrednio sposób myślenia urzędnika o prawie ustanowionym przy ustalaniu podstawy prawnej i faktów prawnych w procesie stosowania prawa. Wykładnia przepisów prawnych i zastosowanie pozyskanych z nich norm prawnych w praktyce urzędniczej realizuje się tak z perspektywy normatywnej, jak i z perspektywy opisowej. Interpretacja decyzji administracyjnej w perspektywie normatywnej i opisowej w tabeli 1.

Tabela 1. Elementy normatywne i opisowe w decyzji administracyjnej

\begin{tabular}{|c|c|c|c|c|c|c|}
\hline \multirow{2}{*}{ Lp } & \multirow[b]{2}{*}{$\begin{array}{l}\text { KONSTRUKCJA } \\
\text { TEKSTU }\end{array}$} & \multicolumn{2}{|c|}{ 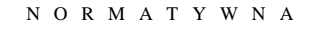 } & \multicolumn{2}{|c|}{$\begin{array}{lllllll}O & P & I & S & O & W & A\end{array}$} & \multirow[b]{2}{*}{$\begin{array}{l}\text { PRZEPISY } \\
\text { PRAWNE }\end{array}$} \\
\hline & & T R E Ś Ć & $\begin{array}{c}\text { RODZAJ } \\
\text { INFORMACJI }\end{array}$ & T R E Ś Ć & $\begin{array}{c}\text { RODZAJ. } \\
\text {.INFORMACJI }\end{array}$ & \\
\hline 1 & $\begin{array}{c}\text { nadawca } \\
\text { decyzji }\end{array}$ & - & $\begin{array}{c}\text { presupozycja, } \\
\text { że jest to organ } \\
\text { uprawniony } \\
\text { do załatwienia } \\
\text { sprawy }\end{array}$ & $\begin{array}{c}\text { nazwa } \\
\text { organu } \\
\text { wydającego } \\
\text { decyzję } \\
\text { i znak } \\
\text { decyzji }\end{array}$ & $\begin{array}{c}\text { komunikat } \\
\text { o tym, } \\
\text { kto wydał } \\
\text { decyzję, } \\
\text { podany } \\
\text { eksplicytnie }\end{array}$ & art. 104 k.p.a. \\
\hline 2 & $\begin{array}{c}\text { typ } \\
\text { komunikatu }\end{array}$ & - & $\begin{array}{l}\text { presupozycja } \\
\text { o właściwości } \\
\text { gatunku tekstu }\end{array}$ & $\begin{array}{c}\text { decyzja } \\
\text { administra- } \\
\text { cyjna }\end{array}$ & $\begin{array}{c}\text { komunikat } \\
\text { o gatunku } \\
\text { tekstu, } \\
\text { podany } \\
\text { eksplicytnie }\end{array}$ & art. 104 k.p.a. \\
\hline 3 & $\begin{array}{c}\text { podstawa } \\
\text { normatywna }\end{array}$ & $\begin{array}{l}\text { sygnatury } \\
\text { tekstów } \\
\text { ustawodaw- } \\
\text { czych }\end{array}$ & $\begin{array}{c}\text { presupozycja, } \\
\text { że organ } \\
\text { administracji } \\
\text { aktualizuje } \\
\text { obowiązek } \\
\text { wyznaczony } \\
\text { mu przez } \\
\text { ustawodawcę }\end{array}$ & $\begin{array}{l}\text { sygnatury } \\
\text { tekstów } \\
\text { ustawodaw- } \\
\text { czych }\end{array}$ & $\begin{array}{c}\text { komunikat } \\
\text { informujący, } \\
\text { na jakiej pod- } \\
\text { stawie roboty } \\
\text { można rozpo- } \\
\text { cząć } \\
\text { po wydaniu } \\
\text { decyzji } \\
\text { na budowę, } \\
\text { podany } \\
\text { eksplicytnie }\end{array}$ & $\begin{array}{c}\text { art. } 28, \text { art. } 33 \\
\text { ust. } 1, \\
\text { art. } 34 \text { ust. } 4 \text {, art. } \\
54 \text { lub art. } 55 \text {, } \\
\text { art. } 36 \text {, art. } 81 \\
\text { ust. } 1 \text { pkt 1) } \\
\text { ustawy Prawo } \\
\text { budowlane } \\
\text { oraz art. } 104 \\
\text { k.p.a. }\end{array}$ \\
\hline 4 & $\begin{array}{c}\text { zdanie } \\
\text { deontyczne }\end{array}$ & $\begin{array}{c}\text { zatwierdzenie } \\
\text { projektu } \\
\text { budowlanego } \\
\text { i pozwolenie } \\
\text { na budowę }\end{array}$ & $\begin{array}{l}\text { metanorma } \\
\text { wysłowiona } \\
\text { eksplicytnie }\end{array}$ & - & - & $\begin{array}{c}\text { art. } 104 \text { k.p.a. } \\
\text { art. } 33 \text { i art. } 34 \\
\text { ust. } 4 \\
\text { oraz art. } 12 \mathrm{i} \\
\text { art. } 28 \text { ust. } 2 \\
\text { ustawy Prawo } \\
\text { budowlane }\end{array}$ \\
\hline 5 & $\begin{array}{c}\text { podciągnięcie } \\
\text { stanu } \\
\text { faktycznego } \\
\text { pod przepisy } \\
\text { prawne }\end{array}$ & - & - & $\begin{array}{c}\text { opis } \\
\text { zamierzenia } \\
\text { budowlanego } \\
\text { i wniosku } \\
\text { o pozwolenie } \\
\text { na budowę }\end{array}$ & $\begin{array}{c}\text { komunikat } \\
\text { o warunkach } \\
\text { i okoliczności } \\
\text { obowiązywania } \\
\text { decyzji, } \\
\text { podany } \\
\text { eksplicytnie }\end{array}$ & $\begin{array}{c}\text { art. } 36, \text { art. } 42 \\
\text { i art. } 54 \\
\text { ustawy } \\
\text { Prawo } \\
\text { budowlane }\end{array}$ \\
\hline 6 & pouczenie & - & - & $\begin{array}{c}\text { pouczenie } \\
\text { o odwołaniu } \\
\text { się } \\
\text { od decyzji }\end{array}$ & $\begin{array}{c}\text { komunikat } \\
\text { o możliwości } \\
\text { odwołania się } \\
\text { od decyzji, } \\
\text { podany } \\
\text { eksplicytnie }\end{array}$ & - \\
\hline
\end{tabular}


Sformułowaniem zdania deontycznego starosta-decydent sugeruje, że w systemie prawnym są takie normy, które upoważniają go do wydania decyzji o ostatecznym zezwoleniu na budowę. Powołując się na normę wysłowioną w art. 104 k.p.a. presuponuje: 1) swoje kompetencje do wydania decyzji, 2) jako typu komunikatu. Natomiast przywołane przepisy prawa budowlanego presuponują, że: 3) roboty budowlane można rozpocząć na podstawie ostatecznej decyzji o pozwoleniu na budowę (art. 28) całego zamierzenia budowlanego (art. 33 ust. 1). Projekt budowlany podlega zatwierdzeniu $\mathrm{w}$ decyzji o pozwoleniu na budowę (art. 34 ust. 4.). W decyzji o pozwoleniu na budowę określa się szczegółowe warunki prowadzenia robót budowlanych oraz zamieszcza się informację o obowiązkach i warunkach wynikających $\mathrm{z}$ art. 54 lub art. 55, a te artykuły stanowią, że podstawą do wykonywania samodzielnych funkcji technicznych $\mathrm{w}$ budownictwie jest wpis nazwiska projektanta do centralnego rejestru samorządu zawodowego; również że obszar oddziaływania obiektu obejmuje nieruchomość oznaczoną nr ewid. 532 w miejscowości Wronki, o czym mowa w art. 28 ust 2. Sentencja decyzji 4) zatwierdza projekt budowlany i pozwolenie na budowę w oparciu o przepis art. 104 k.p.a. oraz art. 33 i 34 pkt. 4 oraz art. 12 i 28 ust. 2 ustawy Prawo budowlane.

W perspektywie opisowej decydent komunikuje: 1) kto, 2) jaką, 3) na jakiej podstawie wydaje decyzję, 4) jakie przepisy prawa budowlanego określają warunki zabezpieczenia terenu budowy w uzasadnieniu decyzji. Decydent 5) podciąga stan faktyczny sytuacji prawnej pod zinterpretowaną podstawę normatywną decyzji w przepisach art. 36, art. 42 i art. 54 ustawy Prawo budowlane. Tekst decyzji kończy się 6) pouczeniem o odwołaniu od decyzji ${ }^{4}$.

2.2. Normy postępowania i zdania deontyczne to wypowiedzi dyrektywalne. Zdania deontyczne tworzą konstrukcję rzeczywistości prawnej przez autorytatywne stwierdzenie faktu prawnego ze względu na treść określonej normy prawnej generalnej. „Norma czyjegoś postępowania to wyrażenie dyrektywalne sformułowane w określonym języku, które określonym podmiotom (adresatom tej normy) nakazuje albo zakazuje określone zachowanie w określonych okolicznościach” (Redelbach 1993: 73). Normy prawne są formułowane w języku prawnym w formie zdań normatywnych. Jednostką tekstową jest przepis prawny. Zdania deontyczne to zdania „stwierdzające, że ze względu na treść określonej normy takie

\footnotetext{
${ }^{4}$ Kolejne numery od 1) do 6) odsyłają do pierwszej rubryki w tabeli 1. 38
} 
a takie czyny są w danych okolicznościach przez tę normę takim a takim podmiotom nakazane, zakazane, czy też są ze względu na nią dozwolone (niezakazane), fakultatywne (nienakazane), czy też indyferentne (ani nakazane, ani zakazane)" (Redelbach, Wronkowska, Ziembiński 1993: 76).

W dialogu asymetrycznym między urzędem reprezentowanym przez autora decyzji administracyjnej a obywatelem wzrasta napięcie między nadawcą a odbiorcą komunikatu $\mathrm{w}$ miarę formułowania w tekście treści presuponowanych. W odbiorze treści decyzji uwzględnia się presuponowany obowiązek organu administracji, uprawnionego do wydania decyzji w formie odpowiedniego gatunku pisma urzędowego. Odbiorca tekstu traktuje zatwierdzenie projektu budowlanego i pozwolenie na budowę jak normę prawną indywidualną. Komunikacja jest zorientowana na obowiązywanie postanowień decyzji oraz na zabezpieczenie decyzji przed jej unieważnieniem.

Przepisy prawne, na podstawie których została wydana decyzja administracyjna, dokładnie wyznaczają jej treść, a organ kompetentny jedynie aktualizuje normy prawne wysłowione w tych przepisach i zabezpiecza swoje interesy urzędnicze przywołaniem głównych celów i planów ustawodawcy, aby nie można mu było zarzucić, że wydał merytorycznie złą decyzję. Przez paralelę można decyzję administracyjną porównać do wyroku sądowego.

2.3. Według zasad językoznawstwa tekstowego modele produkcji i recepcji tekstu nawiązują do retoryki, począwszy od planowania wypowiedzi z orientacją na cel, poprzez znalezienie myśli, rozwinięcie myśli w przestrzeni wiedzy, wyrażenie myśli z uwzględnieniem preferencji oraz $\mathrm{z}$ wyraźnym wskazaniem na problem, po syntezę gramatyczną i uporządkowanie linearne (Beaugrande, Dressler 1990: 62-66). Odtworzenie tekstów w zasadzie przebiega w odwrotnym kierunku, lecz nie pod każdym względem. Odbiorca naśladuje proces produkcji tekstu, ale dochodząc do głównych jego idei, tworzy tekst własny. Jego zadaniem jest dokonać recepcji tekstu macierzystego i zastosować przepisy ustawy. W decyzji musi zatem wpisać postanowienie ustawy w inny kontekst sytuacyjny.

Decyzja jest spełnieniem czynności konwencjonalnej przy rozstrzyganiu problemów prawnych. Artefakty ustawowych tekstów prawnych są przedmiotem przetwarzania co do planów i celów, według których przebiega tworzenie i odbiór tekstów. Tekst prawny ma wpływ na tworzenie tekstu decyzyjnego przez jego więź regulacyjną z kontekstem, lecz jako tekst głoszący prawdę. Twórcze odczytanie tekstu praw- 
nego i wydanie decyzji w zgodzie $\mathrm{z}$ punktem widzenia ustawodawcy staje się planem i celem działania urzędu.

\section{Strategie dyskursywne w dyskursie prawniczym}

Tekst decyzji nie jest autonomiczny i nie można go odłączyć od tekstu aktów ustawodawczych. Organizuje się wokół struktury tekstu prawnego, wchodzi z nim w grę poprzez zespół wiedzy o prawie i poprzez ogólny kompleks przekonań.

3.1. Podstawą odbioru i wykorzystania postanowień ustawy jest przekonanie, że pomiędzy przedmiotami i sytuacjami $\mathrm{w}$ ustawie a przedmiotami i sytuacjami należącymi do świata realnego zachodzi stosunek podobieństwa, oraz że to, co uważa się za rzeczywistość postulowaną w systemie norm prawnych, w decyzji staje się rzeczywistością zinterpretowaną i zaktualizowaną. Odbiór tekstu prawnego przez urzędnika odbywa się w stylu ekspresywnym wobec ustawodawcy, bowiem strategią dyskursywną ustawodawcy jest stanowcze żądanie, by stosować przepisy prawne w obrocie prawnym. Strategią dyskursywną urzędnika jest powoływanie się na te przepisy, bowiem tekst decyzji pośredniczy w wiedzy o treści tekstów prawnych wszystkich zainteresowanych uczestników dyskursu urzędowego, tj. urzędu, strony żądającej decyzji i środowiska prawniczego.

3.2. Rezultat przetwarzania macierzystych tekstów prawnych na teksty decyzji administracyjnych jest podobny w gronie wszystkich członków wspólnoty komunikatywnej. Proces przetwarzania przebiega według wyuczonego wzoru przetwarzania. Urzędnik musi uwzględniać cele i plany ustawodawcy, reagować na nie przy tworzeniu decyzji według modeli, które rządzą użyciem tekstu macierzystego. Inaczej posługiwanie się tekstem ustawy byłoby zakłócone. Zakłócenie następuje, kiedy kontekst obowiązywania decyzji nie odpowiada sytuacji prawnej przewidzianej w tekście prawnym i jest podstawą do odwołań ze względu na błąd merytoryczny, błąd językowy lub niezrozumiałość przekazu.

3.3. Decyzja administracyjna ma charakter formuliczny: składa się z decyzji właściwej i uzasadnienia. Decyzja właściwa wpisuje się w kontekst poznania prawa formułą zdania deontycznego przez przywołanie odpowiednich postanowień przepisów prawnych. W uzasadnieniu 
chodzi o to, jakie argumenty można przytoczyć na poparcie podjętej decyzji, która podlega kontroli instancyjnej w ramach procedury.

Semantyczna i formalna strona decyzji nie podlega ocenie językoznawcy. Na przykładzie analizowanej decyzji warto zwrócić uwagę na to, w jakim wymiarze spełnia ona warunki tekstu przyjaznego odbiorcy.

1) Zdanie kierowane do klienta typu: „Na postawie art. [...] po rozpatrzeniu wniosku [...] zatwierdzam projekt budowlany i udzielam Państwu pozwolenia na budowę [...]" rzetelnie informują osobę składającą wniosek o pozytywnym załatwieniu sprawy.

2) Niestety, struktura tekstu decyzji może być tak skonstruowana, że w jednym długim zdaniu zawarte są wszystkie części normatywne tekstu, podzielone przecinkami, dwukropkami, nawet kropkami, po których zdanie ma dalszy ciąg. Wewnątrz tego zdania znajdują się punkty oznaczone liczbowo lub wydzielone innymi znakami planu tekstu. Graficzny układ tekstu wspomaga rozumienie treści decyzji, lecz tok rozumienia zakłócają błędy gramatyczne i interpunkcyjne, gdy autor tekstu ignoruje zasady składni w języku polskim. Tekst:

„zatwierdzam projekt budowlany i udzielam Państwu Antoniemu P. i Marii P. pozwolenia na budowę budynku mieszkalnego jednorodzinnego - obiekt budowlany kategorii I [...] w miejscowości Wronki, gm. Owczary. wg projektu budowlanego opracowanego przez:

1. Projekt zagospodarowania działki - mgr inż. arch. Jakub M., upr. bud. nr 2985 upoważniające do sporządzania projektów budowlanych [...], z zachowaniem następujących warunków:

mógłby brzmieć:

„zatwierdzam projekt budowlany i udzielam Państwu Antoniemu i Marii P. pozwolenia na budowę budynku mieszkalnego jednorodzinnego, który jest obiektem budowlanym kategorii I, [...] w miejscowości Wronki, gm. Owczary, według:

1. projektu zagospodarowania działki opracowanego przez mgr inż. arch. Jakuba M., posiadającego uprawnienia budowlane $\mathrm{nr} 2985$ upoważniające do sporządzania projektów budowlanych [...], z zachowaniem następujących warunków:

3) Urząd nie może odbierać komunikatu ustawodawczego w innym kodzie niż został napisany. Rolą urzędnika jest wpisanie się w sytuację komunikacyjną w jakiej powstał tekst ustawy, a struktura tekstu ustawy ma implikować sytuację komunikacyjną urzędu. Idealny wzorzec lektury zakłada bowiem różne odczytania, lecz zawsze w tym 
samym kodzie. Toteż w tekście decyzji przywołuje się przepisy ustawy. Zob. tabela 2.

Tabela 2. Porównanie tekstu ustawy z tekstem decyzji

\begin{tabular}{|c|c|}
\hline TEKST USTAWY & TEKST DECYZII ADMINISTRACYJNEJ \\
\hline 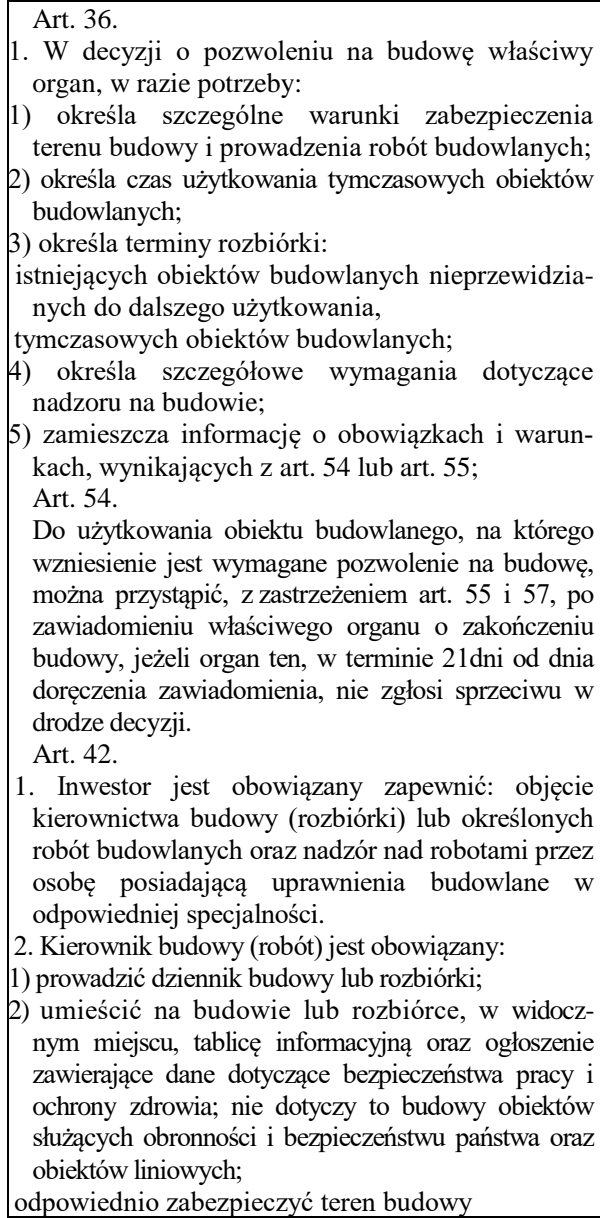 & $\begin{array}{l}\text {...z zachowaniem następujących warunków, } \\
\text { zgodnie z art. ust. } 1 \text { oraz art. } 42 \text { ust. } 2 \text { i } 3 \text { ustawy } \\
\text { - Prawo budowlane: } \\
\text { 1. Szczegółowe warunki zabezpieczenia } \\
\text { terenu budowy: } \\
\text { 2. Czas o zakończeniu budowy co najmniej } 21 \\
\text { dni przed zamierzonym terminem przystąpie- } \\
\text { nia do użytkowania, } \\
\text { 3. Termin rozbiórki: } \\
\text { 1) istniejących obiektów budowlanych } \\
\text { nieprzewidzianych do dalszego użytkowa- } \\
\text { nia: } \\
\text { 2) tymczasowych obiektów budowlanych } \\
\text { 4. Szczegółowe wymagania dotyczące } \\
\text { nadzoru w budowie: } \\
\text { 5. Inwestor jest zobowiązany: } \\
\text { 1) zawiadomić Powiatowego Inspektora } \\
\text { Nadzoru Budowlanego w [...], o zakoń- } \\
\text { czeniu budowy co najmniej } 21 \text { dni przed } \\
\text { zamierzonym terminem przystąpienia do } \\
\text { użytkowania, }\end{array}$ \\
\hline
\end{tabular}

Interpretacja podstawy normatywnej decyzji sprowadza się: 1) do zmiany konwencji ramy tekstowej przez wprowadzenie nowych jednostek redakcyjnych tekstu urzędowego w miejsce jednostek redakcyjnych tekstu prawnego; 2) do zastosowaniu tekstu przepisów ustawy w konkretnej sytuacji prawnej; 3) oraz do opuszczenia tych fragmentów 
przepisów prawnych, które nie odnoszą się do postanowień decyzji. Przytaczanie dosłowne obszernych fragmentów przepisów prawnych burzy jednak harmonię stylistyczną tekstu decyzji.

W wykładni prawa uwzględnia się konteksty odkrycia i uzasadnienia, wyróżnione przez Hansa Reichenbacha i spopularyzowane przez Karla Poppera w jego teorii trzech światów - przedmiotów fizycznych, przeżyć psychicznych i obiektywnych treści przeżyć psychicznych. Świat trzeci to świat obiektywnych treści przeżyć psychicznych - problemów, teorii i uzasadnień. Wobec tego w analizie decyzji interpretacyjnych prawa należy przyjąć, że przedmioty fizyczne to osoby i rzeczy w danej sytuacji prawnej należące do świata pierwszego; kontekst odkrycia miałby należeć do świata drugiego; kontekst uzasadnienia - do świata trzeciego (Spyra 2006: 23-24).

3.4. Zastrzeżenia poprawnościowe nie dotyczą zatem konstrukcji decyzji administracyjnej ani zasad jej organizacji gramatycznej i stylistycznej. Konwencjonalność ramy tekstowej, sposób formułowania wykładników referencyjnych i kompozycja korpusu tekstu decyzji przynależą do gatunku mowy oficjalnej, a zbliżenie stylistyczne i socjologiczne do ustandaryzowanego języka tekstów prawnych zabezpiecza decyzję przed unieważnieniem przez organy administracyjne wyższego stopnia. Ważne jednak, aby język pism urzędowych był przyjazny obywatelom dzięki gramatycznej i stylistycznej poprawności. Lecz gramatyczna i stylistyczna poprawność tekstu istotna ze względu na zrozumiałość przekazu i prestiż urzędu - należy do idiolektów urzędników, a nie do socjolektu urzędowego.

\section{Dekodowanie ustawy w zarządzeniu administracyjnym}

Zarządzenie jest werdyktem władzy nakazującym podwładnym określone postępowanie. Jako akt normatywny nie stanowi źródła powszechnie obowiązującego prawa, lecz ma charakter wewnętrzny i obowiązuje adresata zarządzenia podległego organowi wydającemu zarządzenie.

4.1. Perspektywa normatywna i perspektywa opisowa komunikowania treści prawnych w zarządzeniach wydawanych przez urzędy ma uzasadnienie teoretyczne. Dekodowanie norm postępowania na 
podstawie przepisów prawnych polega na odtworzeniu wypowiedzi o kształcie normy, a następnie na ustaleniu sensu zwrotów występujących w odtworzonych wypowiedziach. Strategie dekodowania tekstu prawnego opracowane zostały $\mathrm{w}$ derywacyjnej koncepcji wykładni prawa. Tabela 3 przedstawia dekodowanie tekstu ustawy w zarządzeniu.

Tabela 3. Strategie dekodowania tekstu ustawy w zarządzeniu

\begin{tabular}{|c|c|c|c|c|}
\hline Lp. & $\begin{array}{l}\text { DERYWACYJNA } \\
\text { KONCEPCJA } \\
\text { WYKŁADNI } \\
\text { PRAWA } \\
\end{array}$ & $\begin{array}{c}\text { CZYNNOŚCI } \\
\text { INTERPRETACYJNE } \\
\text { I WYKŁADNIA } \\
\text { TEKSTU } \\
\end{array}$ & $\begin{array}{c}\text { ODNIESIENIE } \\
\text { WYRAŻEŃ } \\
\text { NORMOKSZTAETNYCH }\end{array}$ & $\begin{array}{c}\text { WYPOWIEDZI } \\
\text { PRZETWORZONE }\end{array}$ \\
\hline 1. & $\begin{array}{c}\text { reguły } \\
\text { interpretacyjne } \\
\text { przekładu }\end{array}$ & $\begin{array}{l}\text { odtwarzanie } \\
\text { norm } \\
\text { prawnych }\end{array}$ & $\begin{array}{l}\text { presupozycja } \\
\text { formuł } \\
\text { idiomatycznych }\end{array}$ & $\begin{array}{c}\text { norma } \\
\text { kompetencyjna: }\end{array}$ \\
\hline 2. & $\begin{array}{c}\text { reguły } \\
\text { inferencyjne } \\
\text { wnioskowań } \\
\text { prawniczych }\end{array}$ & $\begin{array}{c}\text { tworzenie } \\
\text { dalszych norm } \\
\text { w zarządzeniu }\end{array}$ & $\begin{array}{l}\text { analogia metanorm } \\
\text { do norm prawnych }\end{array}$ & $\begin{array}{l}\text { zarządzenie wydane } \\
\text { przez kompetentny } \\
\text { organ administracji }\end{array}$ \\
\hline 3. & $\begin{array}{c}\text { reguły } \\
\text { kolizyjne }\end{array}$ & $\begin{array}{l}\text { uzasadnianie } \\
\text { zarządzenia }\end{array}$ & $\begin{array}{c}\text { eliminowanie } \\
\text { niezgodności norm } \\
\text { wyinterpretowanych } \\
\text { i wyinferowanych } \\
\text { z ustawy }\end{array}$ & $\begin{array}{c}\text { uzasadnienie } \\
\text { wyboru normy praw- } \\
\text { nej uznanej } \\
\text { przez urzędnika } \\
\text { za obowiązującą }\end{array}$ \\
\hline
\end{tabular}

Są to reguły trojakiego rodzaju: interpretacyjne, inferencyjne i kolizyjne (Redelbach, Wronkowska, Ziembiński 1993: 203-21). Przykładem jest zarządzenie wojewody dotyczące wyrażenia zgody na zbycie lokalu mieszkalnego będącego własnością Skarbu Państwa, zob. analiza wykładni przepisu prawnego w celu pozyskania i zastosowania do wydania zarządzenia wojewody zakodowanych $\mathrm{w}$ nim norm postępowania administracyjnego ${ }^{5}$. Porównanie przepisu ustawy z zarządzeniem wydanym na jej podstawie może być następujące.

Art. 11. 2. Jeżeli przepisy ustawy wymagają udzielenia zgody przez radę, sejmik lub wojewodę, wyrażenie zgody, z wyjątkiem zgody, o której mowa $\mathrm{w}$ art. 46 ust. 4, następuje odpowiednio w drodze uchwały rady lub sejmiku albo zarządzenia wojewody wymaganego w terminie miesiąca od złożenia odpowiedniego wniosku przez starostę.

\footnotetext{
5 Analiza językoznawcza materiału empirycznego uwzględnia przepisy prawne obowiązujące w okresie wydawania dokumentów administracyjnych.
} 
Art.34.1. W przypadku zbywania nieruchomości osobom fizycznym i prawnym pierwszeństwo $\mathrm{w}$ ich nabyciu, $\mathrm{z}$ zastrzeżeniem art.216a, przysługuje osobie, która spełnia jeden z następujących warunków:

[...]

3) jest najemcą lokalu mieszkalnego, a najem został nawiązany na czas nieoznaczony.

Art. 47.1. Jednostka organizacyjna sprawująca trwały zarząd może zgłosić właściwemu organowi wniosek o wydanie decyzji o wygaśnięciu tego zarządu do całej nieruchomości lub jej części, jeżeli stała się dla niej zbędna. Złożenie wniosku powinno być poprzedzone uzyskaniem zgody organu nadzorującego jednostkę organizacyjną.

Art. 67. 3. Przy sprzedaży nieruchomości w drodze bezprzetargowej, o której mowa w art. 37 ust. 2 i 3, cenę nieruchomości ustala się w wysokości nie niższej niż jej wartość, z zastrzeżeniem ust. $3 \mathrm{a}$.

3a. Jeżeli nieruchomość jest sprzedawana w drodze bezprzetargowej w celu realizacji roszczeń przysługujących na mocy niniejszej ustawy lub odrębnych przepisów, cenę nieruchomości ustala się w wysokości równej jej wartości.

[Ustawa o gospodarce nieruchomościami]

\section{Zarządzenie}

Wojewody Kazimierza M. w sprawie wyrażenia zgody na odstąpienie od przetargowego trybu wynajęcia, zawarcie umów najmu oraz zbycie w drodze bezprzetargowej na rzecz najemców lokali mieszkalnych

Na podstawie art. 13 ust. 2 i 2a, w związku z art. 11 ust. 2 ustawy z dnia 21 sierpnia 1997 r. o gospodarce nieruchomościami (Dz. U. z 2010 r. Nr 102, poz. 651 z późn. zm.), zarządza się co następuje:

$\S 1$. Wyraża się zgodę na zbycie lokalu mieszkalnego położonego $\mathrm{w}$ Owczarach $[\ldots]$.

§ 2. Zbycie lokalu mieszkalnego opisanego w ust. 1 nastąpi na rzecz Pana Piotra T. jako najemcy posiadającego umowę najmu zawartą na czas nieoznaczony, któremu zgodnie z art. 34 ust. 1 pkt. 3 ustawy z dnia 21 sierpnia 1997 r. o gospodarce nieruchomościami przysługuje pierwszeństwo w nabyciu tego lokalu mieszkalnego, za cenę określoną w sposób przewidziany w art. 67 ust. 3 tej ustawy.

§ 3. Zbycie lokalu mieszkalnego opisanego w ust. 1 nie może nastąpić przed uprawomocnieniem się decyzji Starosty Wacława K. o wygaśnięciu prawa trwałego zarządu ustanowionego na rzecz Komendy Wojewódzkiej Państwowej Straży Pożarnej w Klerykowie, która zostanie wydana w trybie art. 47 ust. 1 ustawy z dnia 21 sierpnia 1997 r. o gospodarce nieruchomościami na wniosek złożony przez Komendanta Wojewódzkiego Państwowej Straży Pożarnej. 
$\S 4$. Określa się warunki bonifikaty od ceny sprzedaży lokali mieszkalnych $[\ldots]$ najemcy bonifikaty $[\ldots]$.

\section{Uzasadnienie}

W myśl art. 13 ust. 2 i $2 \mathrm{a}$, w związku z art. 11 ust. 2 ustawy z dnia 21 sierpnia 1997 r. o gospodarce nieruchomościami nieruchomość może być przedmiotem darowizny $[\ldots]$

W związku z powyższym Starosta Wacław K. zwrócił się do Wojewody Kazimierza M. z wnioskiem o wyrażenie zgody na dokonanie na rzecz Gminy Owczary darowizny niezabudowanych nieruchomości Skarbu Państwa [...]

Mając na uwadze fakt, że Pan Piotr T. zajmuje obecny lokal nie z własnej woli, gdyż z przyczyn od niego niezależnych został do niego przeniesiony z lokalu przy ul. Orkana, w niniejszym przypadku należałoby przeanalizować, czy nie byłoby zasadnym udzielenie najemcy bonifikaty w wysokości odpowiadającej kwocie obniżki, jaką uzyskałby w przypadku zbywania poprzedniego mieszkania $[. ..] \mathrm{z}$ uwagi na stan prawny nieruchomości gruntowej, na której znajdował się budynek [...] i tak nie kwalifikował się do udzielenia bonifikaty.

Mając na uwadze powyższe okoliczności, wydanie zarządzenia w niniejszej sprawie jest zasadne.

[Zarządzenie Wojewody Kazimierza M. z dnia 30 lipca 2012]

Reguły wykładni prawa wyjaśniają rozumienie, przypisują znaczenie i sens przepisów prawnych oraz wyznaczają zakres ich zastosowania do danego stanu faktycznego następująco.

1) Reguły interpretacyjne to reguły przekładu przepisów prawnych na normy. W zarządzeniach były przywołane przepisy aktów normatywnych. Zarządzenie wojewody w sprawie wyrażenia zgody na zbycie lokalu mieszkalnego ma oparcie w ustawie o gospodarce nieruchomościami, a więc $\S 1$ zarządzenia: „Wyraża się zgodę na zbycie lokalu mieszkalnego..." jest świadectwem tego, że wojewoda odczytał idiomatycznie na poziomie dyrektywnym z przepisu prawnego art. 11 ust. 2 Ustawy o gospodarce nieruchomościami przede wszystkim typy norm po pierwsze, normę kompetencyjną uprawniającą go do wydania zarządzenia $\mathrm{w}$ tej sprawie; po drugie, normę sankcjonowaną nakazującą skorzystać z kompetencji:

norma kompetencyjna: *Ustawodawca nakazuje: Niech wyrażenie zgody na zbycie lokalu mieszkalnego następuje w drodze zarządzenia wojewody;

norma sankcjonowana: *Wojewoda ma prawo wyrazić zgodę w formie zarządzenia. 
Następnie odczytał też znaczenie poszczególnych słów w odniesieniu do wyrażeń normokształtnych na poziomie deskryptywnym:

*Wyrażenie zgody może nastąpić w drodze zarządzenia wojewody.

Na pierwszym poziomie urząd zyskuje prawo wydania zarządzenia. Na drugim poziomie zarządzenie jest wypowiedzią stwierdzającą powstanie określonej sytuacji prawnej kwalifikowanej aktem stanowienia prawa. Wszak wiedza prawnicza podpowiada interpretację przepisu prawnego w warstwie językowej na pierwszym poziomie dekodowania jako presupozycję formuł idiomatycznych w strukturze wypowiedzi [Zieliński 2002: 97]. Wojewoda dekoduje intencję ustawodawcy, tworząc tekst meta-performatywny, który określa funkcje ram w akcie wykonania prawa: Wyraża się zgodę.

2) W wydaniu zarządzenia reguły inferencyjne wnioskowania i przesłanki ich stosowania oraz oparte na nich wnioskowania prawnicze prowadzą do tworzenia dalszych norm indywidualnych uznanych za prawnie obowiązujące. Por. kolejne paragrafy zarządzenia wojewody w sprawie zbycia lokalu mieszkalnego w trybie nieprzetargowym. Odtwarzając normy wysłowione w przywołanych przepisach prawnych, urzędnik szuka analogii między stanem faktycznym a zapisem ustawy co do warunków sprzedaży: art. 34 ust. 1 pkt. 3 stanowi o pierwszeństwie sprzedaży najemcy lokalu mieszkalnego; art. 67 ust. 3 ustala cenę nieruchomości w wysokości nie niższej niż jej wartość z zastrzeżeniem ust. 3a, który stanowi, że jeżeli „nieruchomość jest sprzedawana $\mathrm{w}$ drodze bezprzetargowej $\mathrm{w}$ celu realizacji roszczeń przysługujących na mocy niniejszej ustawy lub odrębnych przepisów, cenę nieruchomości ustala się w wysokości równej jej wartości”; art. 47 ust. 1 reguluje tryb wydania decyzji o wygaśnięcie tego zarządu na wniosek jednostki organizacyjnej sprawującej trwały zarząd.

3) W uzasadnieniu decyzji zostały wykorzystane reguły kolizyjne wykładni przez sformułowanie zasady, że przepisy prawne regulujące możliwość uzyskania bonifikaty przy zbyciu lokalu mieszkalnego obejmują więcej sytuacji prawnych, niż to wynika z językowego znaczenia przepisu. Problem udzielenia bonifikaty urzędnik rozpatruje, stosując reguły wykładni, które służą do wyeliminowania niezgodności norm wyinterpretowanych i wywnioskowanych z ustawy o gospodarce nieruchomościami oraz z ustawy o zbywaniu mieszkań będących własnością przedsiębiorstw państwowych $\mathrm{w}$ zastosowaniu do opisywanej 
rzeczywistości prawnej. Ostatecznie eliminuje zasadność bonifikaty przez ustalenie braku zgodności między normą prawną a faktem prawnym.

4.2. W zarządzeniu wojewody prawo realizuje się jako uzasadnienie zgodności lub niezgodności interpretacyjnych z tekstem prawnym lub jako odrzucenie propozycji interpretacyjnych uznanych za niezgodne $\mathrm{z}$ tekstem prawnym. Zarządzenie przypomina styl ustaw chociażby ze względu na strukturalizację tekstu w formie paragrafów, lecz paragrafy poprzedza formuła przywołująca stosowne przepisy prawne oraz uzasadnienie. $Z$ treści uzasadnień wynika, że pismo wojewody kończy postępowanie administracyjne w sprawie najmu lokali mieszkalnych na wniosek stron.

\section{Motywacje i formuly tworzenia stanu faktycznego sytuacji prawnej}

Słusznie twierdzi Maciej Zieliński, że teksty prawne są redagowane zgodnie z przyjętymi od dawna regułami ich odczytywania, ale też reguły interpretacyjne wypracowane $\mathrm{w}$ teorii prawa uwzględniają zastane cechy tekstów prawnych (Zieliński 2002: 59).

5.1. Zatem można przyjąć, że wydanie przez urząd dokumentu zatytułowanego „zarządzenie” jest rezultatem odczytania spójności formalnej i semantycznej w procesie stosowania prawa i przykładem wykładni decyzyjnej prawa wyposażonej w moc wiążącą. Tworzenie takiego pisma jest faktycznie działalnością administracyjną polegającą na sterowaniu normami będącymi treścią przepisów prawnych w działalności urzędowej.

Pośrednikiem pomiędzy ustawodawcą a obywatelem jest urząd jako organ umocowany do pełnienia funkcji administracyjnej. Dokument decyzyjny jest rodzajem wypowiedzi, której celem jest wywołanie określonych stanów rzeczy w stosunkach społecznych. Oficjalny charakter więzi między nadawcą a odbiorcą sprawia, że urzędy posługują się gotowymi wzorcami dokumentów. Cechą gatunkową tych dokumentów jest standardowość oraz oficjalny charakter więzi między nadawcą i odbiorcą (Wojtak 1993: 147-148). Przykładowo następne zarządzenie, tym razem w sprawie darowizny nieruchomości. 


\section{ZARZĄDZENIE}

Wojewody Kazimierza M. (nr poz. Rej. ...) z dnia 2 sierpnia 2012 r. [...] w sprawie wyrażenia zgody na dokonanie darowizny nieruchomości Skarbu Państwa położonych w Owczarach

Na podstawie art. 13 ust. 2 i 2a, w związku z art. 11 ust. 2 ustawy z dnia 21 sierpnia 1997 r. o gospodarce nieruchomościami [...], zarządza się, co następuje $[\ldots]$

$\S 1$ 1. Wyraża się zgodę na dokonanie na rzecz Gminy Owczary darowizny nieruchomości stanowiących własność Skarbu Państwa [...].

Uzasadnienie

W myśl art. 13 ust. 2 i 2 a ustawy [...] nieruchomość może być przedmiotem darowizny dokonanej między Skarbem Państwa a jednostką samorządu terytorialnego. Darowizny nieruchomości stanowiącej własność Skarbu Państwa dokonuje, za zgodą wojewody wyrażoną w formie zarządzenia, starosta wykonujący zadania $\mathrm{z}$ zakresu administracji rządowej $[\ldots]$

W związku z powyższym Starosta Wacław K. zwrócił się do Wojewody Kazimierza M. z wnioskiem o wyrażenie zgody na dokonanie na rzecz Gminy Owczary darowizny niezabudowanych nieruchomości stanowiących własność Skarbu Państwa, położonych w województwie [...].

Mając na uwadze powyższe okoliczności, wydanie zarządzenia [...] jest zasadne.

[Zarządzenie Wojewody Kazimierza M. z dnia 18 sierpnia 2012]

Urzędowy styl języka narzuca zamknięcie tekstu dokumentu w ramach szablonu wymuszane powtarzalnością sytuacji prawnej.

5.2. Części tekstu decyzyjnego - tytuł, sentencja i uzasadnienie - są ze sobą powiązane przez odniesienie tych samych słów do tego samego referenta za pomocą tych samych środków formalnych. Spójność formalna tekstu jest realizowana przez powtarzanie deskrypcji (imienia i nazwiska) stron, powtarzane są też nazwy organów administracji. Użyty został wskaźnik zespolenia zdań: $W$ związku z powyższym. Powtarzane są terminy darowizna, nieruchomość, własność.

5.3. Odniesienie tematyczne zapewnia spójność semantyczną tekstu. Dzięki powtórzeniom tekst dokumentu zyskuje precyzję formalną, natomiast traci potoczystość stylu. Każdy z segmentów tekstu staje się autonomiczną wypowiedzią. Toteż rangę tekstu określa tematyzacja, ponieważ temat jest punktem odniesienia dla całości tekstu. Natomiast remat spełnia funkcję komplementarną do tematu, ponieważ przedstawia to, co jest orzekane w temacie (Duszak 1998: 96). Tematem w zarządzeniu jest przedmiot sprawy (darowizny nieruchomości Skarbu Państwa) wyszczególniony w tytule i powtarzany w kolejnych jednost- 
kach tekstowych. Temat tworzy punkt odniesienia dla całego komunikatu i porządkuje odniesienia tematyczne. Taka progresja (rozbudowa) tematyczna ma znaczenie przy interpretacji tekstu zarządzenia dzięki spójności semantycznej w architekturze tekstu.

Progresja tematyczna nawiązująca do głównego tematu zarządzenia (darowizna) i tematyzująca remat (dokonanie darowizny nieruchomości - wyraża się zgodę na dokonanie darowizny nieruchomości ${ }^{6}$ ) ma znaczenie przy interpretacji tekstu, a stałe odwoływanie się do przepisów ustawy ma eliminować wieloznaczność. Pozycje strategiczne orzekane w remacie wyznaczają sygnały graficzne dla odpowiedniej manipulacji przestrzenią tekstową i prowadzą odbiorcę do identyfikacji procesów przetwarzania informacji (Duszak 1998: 127-128). Wraz z odwołaniem się do przepisów prawnych (art. 13 ust. 2 i 2a, w związku $z$ art. 11 ust. 2 ustawy z dnia 21 sierpnia 1997 r. o gospodarce nieruchomościami...) służą kontekstualizacji poprzez wskazanie, jak tekst wynika z wcześniejszego tekstu prawnego. Wszak istnieje analogia między formalizacją języka prawniczego oraz języka urzędowego przedstawioną według metod lingwistyki tekstu (Marczyk 2004: 157-166). Wewnętrzny podział przestrzeni tekstowej orientuje odbiorcę w świecie teksu, a także wyznacza pozycje strategiczne otwarcia tekstu ( $W$ myśl art. ...) lub jego fragmentu ( $W$ związku z powyższym...), jak również pozycję zamknięcia tekstu (Majac na uwadze powyższe okoliczności...).

4.4. W płaszczyźnie makrostrukturalnej pozycje dla odpowiedniej manipulacji przestrzenią tekstową wyznaczają sygnały graficzne w postaci tytułu i wydzielonych partii tekstu - sentencji i uzasadnienia. Formalizacja i semantyzacja języka zarządzeń i decyzji administracyjnych przekłada się na spójność architektury tekstów.

\section{Zakończenie}

Z analizy lingwistycznej dokumentów urzędowych w postępowaniu administracyjnym wynika, że dokumenty te przedstawiają cel

\footnotetext{
${ }^{6}$ Co do poprawności językowej tego wyrażenia: rzeczownik dokonanie można z powodzeniem opuścić, a sens zdania nie ulegnie zmianie, zob. wyrażenia zgody na darowiznę nieruchomości - wyraża się zgodę na darowiznę nieruchomości.
} 
działania decyzyjnego urzędnika, który wydaje decyzję czy zarządzenie, aby wypełnić obowiązek narzucony mu przez ustawową normę kompetencyjną. Ewokację treści artykułów ustawy w dokumentach administracyjnych należy rozumieć jako konkretyzację przepisów prawnych $\mathrm{w}$ odbiorze $\mathrm{z}$ zachowaniem stylu tekstu macierzystego, a w konsekwencji z powielaniem mechanizmów techniki komunikacyjnej poprzez działania, w których realizuje się funkcjonowanie prawa stanowionego w obrocie prawnym. Proces ten można rozumieć jako przyswojenie wzorców komunikacji przez odbiorcę w obrębie dwóch systemów - w systemie języka prawnego i w systemie języka administracyjnego. Przyswojenie wzorców finalizuje adaptacja do konkretnych sytuacji prawnych.

Decyzyjne teksty administracyjne dokumentują odbiór komunikatów ustawodawcy oraz przetwarzają te komunikaty. Są tekstami o charakterze dyskursywnym, w których czynności lektury nie zostały stematyzowane, lecz odesłane do przepisów prawnych oznaczonych jako artykuły ustaw. Odesłania pokazują pośrednio sposób myślenia urzędnika o prawie stanowionym przy ustalaniu podstawy prawnej i faktów prawnych w procesie stosowania prawa. Wykładnia przepisów prawnych i zastosowanie pozyskanych z nich norm prawnych w praktyce urzędniczej realizuje się tak z perspektywy normatywnej, jak i z perspektywy opisowej.

Decyzje i zarządzenia administracyjne ze względu na sposób odwzorowania treści prawnych $\mathrm{w}$ sferze przyswojenia $\mathrm{i}$ adaptacji można potraktować nie tylko jako „wiedzę o prawie”, przyswojoną tak, jak w podręczniku akademickim, lecz przede wszystkim jako „znajomość prawa”. W efekcie następuje proces uniwersalizacji wiedzy o prawie stanowionym, czyli wpisanie treści ustawodawczych w problematykę własnej wspólnoty przez samodzielne odczytanie i wpisanie tych treści ustawowych w konkretną rzeczywistość prawną. Wyjęte z kontekstu wyjściowego ustawy sensy prawne autor decyzji czy zarządzeń umieszcza w kontekście docelowym - na swoim polet$\mathrm{ku}$ administracyjnym - w wyniku czego przepisy prawne nabierają nowych jakości i znaczeń. Sensy te przechodzą jako źródło inspiracji uświadomionej przez ustawodawcę i są odbierane przez urzędnika, niejako uznane za własne, co jednak nie niweczy momentu, że są dane urzędnikowi z zewnątrz.

Stylistyczna postać tych pism jest świadectwem odbioru reguł ustawodawczych i dokumentem użycia ich $\mathrm{w}$ procesie stosowania prawa 
na zasadzie odwracalności produkcji tekstu w recepcji tekstu. Styl tekstów decyzyjnych determinują z jednej strony formuły języka prawnego jako prawidłowość kulturowa, $\mathrm{z}$ drugiej strony strategie porządkowania reguł i zasad oraz wskazówki wykładni prawa. Eksploatacja wzoru przetwarzania tekstów to wyuczony przebieg odwzorowywania typów tekstów we wszystkich fazach odbioru, a więc w analizie gramatycznej, a także w odzyskiwaniu pojęć i idei prawnych według reguł interpretacyjnych przekładu, reguł inferencyjnych wnioskowań prawniczych oraz reguł kolizyjnych eliminujących niezgodności norm wyinterpretowanych i wyinferowanych z ustawy.

Semantyka i struktura pism urzędowych w postępowaniu administracyjnym zależy od oceny merytorycznej tekstu ustawy przez urzędnika. W socjolekcie urzędniczym uwzględnia się tradycyjnie ukształtowane i obowiązujące w wykładni przepisów prawnych wzorce kulturowe. Błędy językowe piętnowane słusznie jako naruszenie norm poprawnościowych języka oraz ujemnie wpływające na zrozumiałość i przychylność tekstu prawniczego są cechą idiolektów urzędników, czyli takich elementów własnego języka podmiotowego, które wyznaczają wersję języka etnicznego poszczególnych osób.

\section{Bibilografia}

Austin, John Langshaw. 1993. Jak działać słowami. W Mówienie i poznawanie. Rozprawy $i$ wyktady filozoficzne, przeł. Bohdan Chwedeńczuk. Warszawa: Wydawnictwo Naukowe PWN 560 [How to Do Things with Words, 1975].

de Beaugrande, Robert-Alain i Wolfgang Urlich Dressler. 1990. Wstęp do lingwistyki tekstu, przekł. Aleksander Szwedek. Warszawa: PWN.

Duszak, Anna. 1998. Tekst, dyskurs, komunikacja międzykulturowa. Warszawa: Wydawnictwo Naukowe PWN.

Grabias, Stanisław. 1993. Środowiskowe $i$ zawodowe odmiany języka socjolekty. W Encyklopedia Kultury Polskiej XX Wieku, t. 2, Współczesny język polski, red. J. Bartmiński. Wrocław: Wiedza o Kulturze..

Lizisowa, Maria Teresa. 2006. Tekst - kontekst - interpretacja. W poszukiwaniu semiotyczno-dyskursywnych wzorców konkre- 
tyzacji języka. Część pierwsza. Wybrane zagadnienia dyskursu prawnego. Kraków: Collegium Columbinum.

Lizisowa, Maria Teresa. 2009. Performatywne wypowiedzi prawne w aspekcie lingwistyki tekstu. W Prawo $i$ język, red. Anna Mróz, Adam Niewiadomski, Monika Pawelec, 19-36. Warszawa: Uniwersytet Warszawski.

Lizisowa, Maria Teresa. 2012. O formie i treści znaków języka prawnego. W Język współczesnego prawa, red. Adam Niewiadomski, Ewa Szmytelska, 15-41. Warszawa: Uniwersytet Warszawski.

Lizisowa, Maria Teresa. 2016. Komunikacyjna teoria języka prawnego. Poznań: Wydawnictwo Naukowe CONTACT.

Malinowska Ewa. 2001. Wypowiedź administracyjne - struktura i pragmatyka. Opole: Wydawnictwo Uniwersytetu Opolskiego. Malinowski, Andrzej. 2006. Polski język prawny. Wybrane zagadnienia. Warszawa: Wydawnictwo Prawnicze LexisNexis.

Marczyk, Krzysztof. 2004. Formalizacja języka prawniczego praktyki orzeczniczej (na przykładzie tekstu wyroku sądowego wraz z uzasadnieniem. W Język. Prawo. Społeczeństwo, red. nauk. Ewa Malinowska, 157-166. Opole: Wydawnictwo Uniwersytetu Opolskiego.

Redelbach, Andrzej, Sławomira Wronkowska i Zygmunt Ziembiński. 1993. Zarys teorii państwa i prawa. Warszawa: Wydawnictwo Naukowe PWN.

Spyra, Tomasz. 2006. Granice wyktadni prawa. Kraków. Kantor Wydawniczy ZAKAMYCZE.

Studnicki, Franciszek. 1969. Cybernetyka i prawo. Warszawa: Wiedza Powszechna.

Wojtak, Maria. 1993. Styl urzędowy. W Encyklopedia kultury polskiej XX wieku, t. 2, Wspótczesny język polski, red. Jerzy Bartmiński. Wiedza o kulturze, 147-162. Wrocław.

Zieliński, Maciej. 2002. Wykładnia prawa. Zasady. Reguły. Wskazówki. Warszawa: Wydawnictwo Prawnicze LexisNexis.

\section{Akty ustawodawcze}

Kodeks postępowania administracyjnego, Dz.U. 1960 nr 30 poz. 168 z późn. zm. [Dz. U. 2017, poz. 1257].

Ustawa z dnia 7 lipca 1994 r. Prawo budowlane, Dz.U. 1994 Nr 89 poz. 414 z późn. zm. [Dz.U. z 2017 r., poz. 1332]. 
Maria Teresa Lizisowa: Technika komunikowania prawa...

Ustawa z dnia 21 sierpnia 1997 r. o gospodarce nieruchomościami, Dz. U. 1997 Nr 115 poz. 741 [Dz. U. 2016, poz. 2147]. 